\section{References}

${ }^{1}$ Martin, C M, et al, fournal of Infectious Diseases, 1971, 124, suppl P 24.

2 Roe, E, and Lowbury, E J L, Fournal of Clinical Pathology, 1972, 25, 176.

3 Inamatsu, T, Nakauchi, K, and Shimada, K, Proceedings of the 9th International Congress of Chemotherapy, 1976, in press.

${ }^{4}$ Daikos, G K, et al, in Proceedings of the 8th International Congress of Chemotherapy, ed G K Daikos, vol 1, p 427. Athens, Hellenic Society for Chemotherapy, 1973.

5 Meyer, R D, et al, Lancet, 1976, 1, 580.

${ }_{6}$ Tomioka, S, Kobayashi, Y, and Hasegawa, M, Proceedings of the 9 th International Congress of Chemotherapy, 1976, in press.

7 Garrod, L P, Lambert, H P, and O'Grady, F, Antibiotic and Chemotherapy, 4th edn, p 116. London, Churchill Livingstone, 1973.

${ }^{8}$ Waterworth, P M, fournal of Clinical Pathology, 1972, 25, 979.

9 Waitz, J A, et al, Antimicrobial Agents and Chemotherapy, 1972, 2, 431.
${ }^{10}$ Klastersky, J, et al, European fournal of Cancer, 1973, 9, 641.

${ }^{11}$ Crowe, C C, and Sanders, E, Antimicrobial Agents and Chemotherapy, $1973,3,24$

12 Weinstein, R J, Young, L S, and Hewitt, W L, Antimicrobial Agents and Chemotherapy, 1975, 7, 172.

13 Valdivieso, M, et al, Proceedings of the 9th International Congress of Chemotherapy, 1976, in press.

${ }^{14}$ Meyer, R D, et al, Annals of Internal Medicine, 1975, 83, 790.

15 Reynolds, A V, Hamilton-Miller, J M T, and Brumfitt, W, British Medical fournal, 1974, 3, 778 .

${ }^{16}$ Haldane, E B, and van Rooyen, C E, Proceedings of the 9th International Congress of Chemotherapy, 1976, in press.

${ }^{17}$ Price, K E, Godfrey, J C, and Kawaguchi, H, Advances in Applied Microbiology, 1974, 18, 191.

18 George, R H, and Heding, D E, Lancet, 1976, 1, 258.

\title{
Hypertension after renal transplantation
}

\author{
C BACHY， G P J ALEXANDRE，C VAN YPERSELE DE STRIHOU
}

British Medical fournal, 1976, 2, 1287-1289

\section{Summary}

The incidence of hypertension (mean diastolic pressure above $90 \mathrm{~mm} \mathrm{Hg}$ ) was evaluated in 85 patients with renal transplants whose follow-up ranged from 3 to 84 months. Bilateral nephrectomy had been performed in 80 recipients. The proportion of hypertensive subjects rose during the first three months, subsequently stabilised around $50-60 \%$ for up to five years, and then decreased slightly during the next two years. Over the years hypertension fluctuated so that one-third of the initially hypertensive patients became normotensive, and over one-third of the initially normotensive patients became hypertensive.

The main single aetiological factor was renal failure. A significant relation between steroid dosage and blood pressure was found in only a quarter of the hypertensive patients, and in another quarter no cause could be found.

\section{Introduction}

Although hypertension is a well-known complication of renal transplantation, its incidence and causes have been evaluated only in short-term studies soon after the operation. ${ }^{1-6} \mathrm{We}$ undertook this study, firstly, to assess the incidence of chronic hypertension up to seven years after renal transplantation and, secondly, to define its causal factors.

\section{Patients and methods}

From 1 January 1968 to 1 January 1973152 transplantations were performed in 142 patients. At three months $80 \%$ of the grafts were functioning. Immunosuppressive treatment consisted basically of

Renal and Transplantation Units, Cliniques Universitaires St-Pierre, Université de Louvain, Louvain, Belgium

C BACHY, MD, house officer, renal unit

G P J ALEXANDRE, MD, professor of surgery and chief of transplantation unit

C VAN YPERSELE DE STRIHOU, MD, professor of medicine and chief of renal unit azathioprine $(2 \mathrm{mg} / \mathrm{kg}$ body weight) and prednisolone. Actinomycin C and antilymphocyte globulins were given to some patients during the first six months.?

We studied 85 patients ( 52 males and 33 females) whose ages ranged from 7 to 55 years (mean 35.5). They had survived with their first graft for more than three months and were regularly followed up at our clinic. Patients were seen twice weekly during the first six months, weekly during the next six months, then twice monthly, and eventually monthly thereafter. A twice weekly schedule was resumed when rejection occurred.

The transplant originated from a cadaver in 82 cases and from a living relative in three cases. Bilateral nephrectomy was performed in 80 recipients.

Patients' charts were reviewed up to January 1976, so that the potential follow-up ranged from a minimum of 36 months to a maximum of 96 months. Blood pressure at the end of $1,2,3,6,12$, $18,24,36,48,60,72$, and 84 months was calculated by averaging the last five blood pressure readings obtained in the supine position. Mean diastolic pressures exceeding $90 \mathrm{~mm} \mathrm{Hg}$ without treatment or $85 \mathrm{~mm} \mathrm{Hg}$ with a diuretic and a salt-free diet were considered hypertensive. Mean diastolic pressures exceeding $100 \mathrm{~mm} \mathrm{Hg}$ without treatment or $95 \mathrm{~mm} \mathrm{Hg}$ with a diuretic and a salt-free diet were considered severely hypertensive.

Graft function was assessed by averaging the values of the last five serum creatinine determinations obtained at the end of each period. Total prednisolone dosage during each time interval was calculated for every patient.

Renal failure had been caused by chronic glomerulonephritis ( 50 patients), chronic interstitial nephritis including pyelonephritis and analgesic abuse (29 patients), polycystic kidneys ( 3 patients), malignant hypertension ( 2 patients), and renal tuberculosis (1 patient).

\section{Results}

INCIDENCE OF HYPERTENSION

The incidence of hypertension increased over the first three months and stabilised subsequently at around $50-60 \%$ for up to five years after transplantation. It fell thereafter to $40 \%$. Slightly fewer than half the hypertensive patients suffered from severe hypertension (table I).

\section{EVOLUTION OF HYPERTENSION}

The stability of hypertension was assessed in 58 patients whose grafts functioned for at least 36 months. Of 31 patients who were normotensive at three months, 14 had become hypertensive at 36 months. Conversely, of the 27 patients who were hypertensive at three months, nine had become normotensive at 36 months. 
TABLE I-Frequency of hypertension after renal transplantation

\begin{tabular}{|c|c|c|c|c|c|c|c|c|c|c|c|c|}
\hline Months after tr & lantation: & 1 & 2 & 3 & 6 & 12 & 24 & 36 & 48 & 60 & 72 & 84 \\
\hline $\begin{array}{l}\text { No of patients } \\
\% \text { of patients with diastolic BP } \dddot{B} \geqslant 90 \mathrm{~mm} \mathrm{Hg} . . \\
\% \text { of patients with diastolic BP } \gg 100 \mathrm{~mm} \mathrm{Hg}\end{array}$ & $\begin{array}{ll}\cdots & \cdots \\
\cdots & \cdots\end{array}$ & $\begin{array}{r}85 \\
30 \\
8\end{array}$ & $\begin{array}{r}85 \\
32 \\
8\end{array}$ & $\begin{array}{l}85 \\
53 \\
24\end{array}$ & $\begin{array}{l}77 \\
65 \\
34\end{array}$ & $\begin{array}{l}71 \\
61 \\
25\end{array}$ & $\begin{array}{l}62 \\
57 \\
21\end{array}$ & $\begin{array}{l}58 \\
67 \\
26\end{array}$ & $\begin{array}{l}41 \\
50 \\
12\end{array}$ & $\begin{array}{l}36 \\
53 \\
14\end{array}$ & $\begin{array}{l}17 \\
41 \\
12\end{array}$ & $\begin{array}{l}10 \\
40 \\
10\end{array}$ \\
\hline
\end{tabular}

$\mathbf{B P}=$ Blood pressure.

TABLE II-Cardiovascular state, prednisolone dose, and creatinine concentration in comparable groups of patients with and without hypertension

\begin{tabular}{|c|c|c|c|c|c|c|c|c|c|c|c|c|}
\hline & & & \multirow{2}{*}{$\begin{array}{c}\text { No of } \\
\text { patients }\end{array}$} & \multirow{2}{*}{$\begin{array}{c}\text { Mean } \\
\text { age } \\
\text { (years) }\end{array}$} & \multirow{2}{*}{$\begin{array}{c}\text { Mean BP at } \\
60 \text { months } \\
(\mathrm{mm} \mathrm{Hg})\end{array}$} & \multicolumn{3}{|c|}{$\begin{array}{l}\text { Cardiovascular state } \\
\text { at } 60 \text { months }\end{array}$} & \multicolumn{2}{|c|}{$\begin{array}{l}\text { Mean daily } \\
\text { prednisolone (mg) }\end{array}$} & \multicolumn{2}{|c|}{$\underset{(\mu \mathrm{mol} / 1)}{\text { Serum creatinine }}$} \\
\hline & & & & & & $\begin{array}{c}\text { ECG } \\
\text { abnormal* }\end{array}$ & $\begin{array}{l}\text { increased } \\
\text { heart size }\end{array}$ & $\begin{array}{c}\text { Stage } 2 \\
\text { retinopathy }\end{array}$ & $\begin{array}{l}\text { First } \\
12 \text { months }\end{array}$ & $\begin{array}{c}\text { First } \\
60 \text { months }\end{array}$ & $\begin{array}{c}\text { At } \\
3 \text { months }\end{array}$ & $\begin{array}{c}\text { At } \\
60 \text { months }\end{array}$ \\
\hline $\begin{array}{l}\text { Normal BP } \\
\text { Hypertension }\end{array}$ & $\because$ & $\therefore$ & $\begin{array}{l}9 \\
9\end{array}$ & $\begin{array}{l}37 \cdot 2 \\
37 \cdot 6\end{array}$ & $\begin{array}{l}118 / 74 \\
142 / 97\end{array}$ & $\begin{array}{l}1 \\
6\end{array}$ & $\begin{array}{l}1 \\
4\end{array}$ & $\begin{array}{l}5 \\
8\end{array}$ & $\begin{array}{l}26 \\
26\end{array}$ & $\begin{array}{l}16 \cdot 6 \\
15 \cdot 8\end{array}$ & $\begin{array}{r}83 \\
103\end{array}$ & $\begin{array}{l}100 \\
147\end{array}$ \\
\hline
\end{tabular}

*Left ventricular hypertrophy with or without overloaBd. $\mathrm{P}=$ Blood pressure. ECG = Electrocardiogram.

Conversion: SI to traditional units-Creatinine: $1 \mu \mathrm{mol} / 1 \approx 0.0113 \mathrm{mg} / 100 \mathrm{ml}$.

The long-term effect of hypertension on the cardiovascular state was evaluated in nine patients who remained constantly hypertensive for 60 months. Nine patients who remained constantly normotensive during this interval served as controls. Although the cardiovascular state was the same in the two group sat the time of transplantation, it had become clearly worse at 60 months in the hypertensive patients (table II).

CAUSES OF HYPERTENSION

Adrenal steroids-The relation between diastolic blood pressure and steroid dosage was assessed at three months because the variation in the daily prednisolone dose was at its greatest at that time, ranging from 8.5 to $70 \mathrm{mg}$. No statistically significant correlation was obtained either in the whole group or in any subgroup defined by diastolic pressure, renal function, or both (table III). The part played by steroids in hypertension was further assessed by comparing mean prednisolone dosage in the nine patients who remained hypertensive and in the nine patients who remained normotensive for 60 months. No difference was seen in the mean dosage calculated either over the first 12 months or over 60 months (table II). Finally, the influence of steroids on blood pressure was evaluated in 45 patients whose follow-up had lasted at least 36 months and whose diastolic blood pressure and daily prednisolone dose had varied over this time by at least $10 \mathrm{~mm} \mathrm{Hg}$ and $15 \mathrm{mg}$ respectively. A statistically significant

TABLE III-Relation between prednisolone dosage and diastolic blood pressure at 3 months

\begin{tabular}{|c|c|c|c|c|}
\hline \multicolumn{3}{|c|}{ Group } & $\begin{array}{c}\text { No of } \\
\text { patients }\end{array}$ & $\begin{array}{l}\text { Correlation } \\
\text { coefficient }\end{array}$ \\
\hline $\begin{array}{l}\text { All patients .. } \\
\text { Hypertension } \\
\text { Normotension } \\
\text { Creatinine <106 } \\
\text { Creatinine } \\
\text { Hypertension and } \\
\text { Hypertension and } \\
\text { Normotension and } \\
\text { Normotension and }\end{array}$ & $\begin{array}{l}\cdots \\
\cdots \\
\cdots \\
\text { mol/1 } \\
\text { imol/1 } \\
\text { creatinine } \\
\text { creatinine } \\
\text { creatinine } \\
\text { creatinine }\end{array}$ & 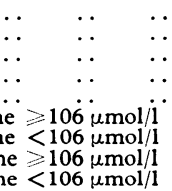 & $\begin{array}{l}85 \\
45 \\
40 \\
46 \\
39 \\
23 \\
22 \\
23 \\
17\end{array}$ & $\begin{array}{r}0.18 \\
0.25 \\
0.12 \\
-0.14 \\
0.30 \\
-0.04 \\
0.26 \\
-0.31 \\
0.08\end{array}$ \\
\hline
\end{tabular}

TABLE IV-Mean creatinine level ( $\mu$ mol/l) as function of blood pressure. Numbers of patients are given in parentheses

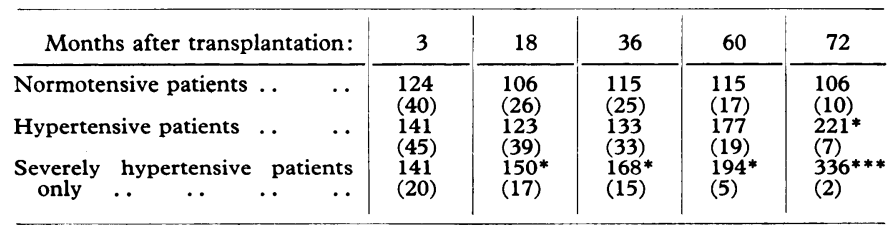

${ }^{*} \mathrm{P}<0.05 ; * * * \mathrm{P}<0.001$ compared with normotensive group.
TABLE V-Patients' prognosis as function of blood pressure at three months

\begin{tabular}{l|c|c|c|c|c|c}
\hline $\begin{array}{c}\text { Blood } \\
\text { pressure } \\
\text { at } \\
3 \text { months }\end{array}$ & $\begin{array}{c}\text { No of } \\
\text { patients at } \\
\text { risk during } \\
\text { this interval }\end{array}$ & $\begin{array}{c}\text { No } \\
\text { under- } \\
\text { going } \\
\text { dialysis }\end{array}$ & $\begin{array}{c}\text { No } \\
\text { who } \\
\text { died }\end{array}$ & $\begin{array}{c}\text { No of } \\
\text { patients at } \\
\text { risk during } \\
\text { this interval }\end{array}$ & $\begin{array}{c}\text { No } \\
\text { under- } \\
\text { going } \\
\text { dialysis }\end{array}$ & $\begin{array}{c}\text { No } \\
\text { who } \\
\text { died }\end{array}$ \\
\hline $\begin{array}{l}\text { Normal } \\
\text { Hypertension }\end{array}$ & 40 & 1 & 8 & 26 & 1 & 5 \\
\hline
\end{tabular}

positive correlation $(P<0.05)$ between the two indices was found in only 12 patients.

Renal function-The mean serum creatinine level was consistently higher in the hypertensive patients than in the normotensive patients, but this difference was statistically significant only at 72 months (table IV). When only severe hypertension was taken into account the difference was even more striking, being significant from 18 months onwards. The relation between renal failure and severe hypertension was further illustrated by the observation that the number of patients with an abnormal serum creatinine concentration ( $>106 \mu \mathrm{mol} / 1$ $(>1.2 \mathrm{mg} / 100 \mathrm{ml}))$ was significantly higher in the severely hypertensive than in the normotensive group ( 13 out of $18 v 11$ out of 28 at 12 months and 5 out of $5 v 8$ out of 17 at 60 months; $\mathrm{P}<0.05\left(\chi^{2}\right.$ test)). Patients with mild hypertension behaved like the normotensive subjects. We found no difference between the hypertensive and normotensive patients in the number of episodes of acute rejection undergone during the first year (mean 1.7 and 1.4 episodes respectively). Respectively, $69 \%$ and $62 \%$ in each group suffered at least one rejection episode.

Renal artery stenosis-Renal arteriography was performed in five of the 85 patients. Renal artery stenosis was found in two. In the other three patients diffuse lesions of the primary and secondary division branches of the renal artery were found.

PROGNOSTIC VALUE OF HYPERTENSION

Table $\mathrm{V}$ presents the outcome at 36 and 60 months according to the patients' blood pressures at three months. The number of deaths was similar in the two groups. This is easily understood, as the causes of death (septicaemia, hepatic disease, gastrointestinal haemorrhage) were unrelated to hypertension or renal failure. Resumption of dialysis, on the other hand, was more common among the hypertensive patients, an observation showing the association between hypertension and progressive renal insufficiency.

The evolution towards renal failure in hypertensive patients may be slow: serum creatinine concentrations remained normal in the nine patients who were constantly normotensive over the 60 months, but they rose in four of the nine constantly hypertensive patients. Nevertheless, renal function in the other five patients with hypertension remained stable throughout the five years. 


\section{Discussion}

A high incidence of hypertension, ranging from 30 to $80 \%$ has been reported within two to 12 months after transplantation. ${ }^{2-6}$ We have extended these observations by showing that about half of a large series of patients were hypertensive up to six years after transplantation.

Interestingly, the stability of the incidence of hypertension over the years was only apparent, as blood pressure had returned to normal by three years in a third of the patients who were hypertensive at three months, whereas over a third of the initially normotensive subjects had become hypertensive by three years. As a result, although never more than $66 \%$ of the patients had hypertension at any one time, $82 \%$ of all transplanted patients were hypertensive at one time or another during follow-up.

The causes of hypertension in renal transplant recipients are multiple. Our data suggest that, contrary to previous findings, ${ }^{5}$ the dose of corticosteroids is not by itself an important factor. A significant correlation between blood pressure and steroid dosage was found during follow-up in only a quarter of the hypertensive patients. Three months after transplantation no relation was found between steroid dose and diastolic blood pressure-an observation that agrees with others. ${ }^{2-4}$ Finally, there was no significant difference in the steroid intake of patients whose blood pressure remained consistently raised over five years compared with values in patients with normal pressures over five years. The patients' own kidneys ${ }^{16}$ could not be incriminated because 80 of the 85 patients had undergone bilateral nephrectomy. Renal artery stenosis was observed in only two patients, but renal angiography was performed only in patients with severe refractory hypertension. In a prospective study, ${ }^{8}$ incidences as high as $23 \%$ were reported, though renal artery stenosis was also noted in normotensive patients, which underlines the fact that the association between renal artery stenosis and hypertension may not always be causal. At the very least, our data suggest that renal artery stenosis is not a common cause of hypertension after renal transplantation.

In our series renal failure was the most significant factor associated with the development of hypertension, especially among severely hypertensive patients. Many more of the patients with severe hypertension had an abnormal creatinine concentration, and the mean concentration in this group was significantly higher than that of the normotensive patients.
Our data should not obscure the fact that $20-25 \%$ of hypertensive patients had both normal renal function and a daily steroid dose of $10 \mathrm{mg}$ or less 24 to 60 months after transplantation. Smellie et $a l^{9}$ and Malekzadeh et $a l^{10}$ have also reported hypertension in transplanted patients with a normal renal function. Arteriography in some of their patients showed intrarenal arterial lesions that were tentatively attributed to subclinical rejection episodes. Similar lesions might have caused hypertension in some of our patients. They might have accounted for the progressive slow decrease in renal function observed over five years in four constantly hypertensive patients, a finding in sharp contrast with the stability of renal function in nine other patients whose blood pressure remained normal over the same period. Alternatively, the possibility that essential hypertension develops in a population of young adults should be considered despite our finding that age bore no relation to the frequency of hypertension at one year. Similarly, hypertension was no more prevalent in the patients whose original illness had been complicated by hypertension than in those who had remained normotensive. Finally, Bianchi et $a l^{11}$ have provided experimental evidence suggesting the intriguing possibility that the transplanted kidney, coming from a donor with a family history of essential hypertension, might transmit this tendency to the recipient. The evaluation of these hypotheses will require further investigations.

This work was supported by a grant from the Fonds de la Recherche Scientifique Médicale.

Requests for reprints should be addressed to Dr C van Ypersele, Renal Unit, Cliniques Universitaires St-Pierre, 3000 Louvain, Belgium.

\section{References}

1 Papadimitriou, M, Chisholm, G D, and Shackman, R, Lancet, 1969, 1, 902.

2 Coles, G A, et al, Postgraduate Medical fournal, 1972, 48, 399.

${ }^{3}$ Cohen, S L, British Medical fournal, 1973, 3, 78.

4 Legrain, M, et al, fournal d'Urologie et de Néphrologie, 1973, 79, 444.

5 Popovtzer, M M, et al, Circulation, 1973, 47, 1297.

${ }_{6}^{6}$ Grünfeld, J P, et al, Clinical Science and Molecular Medicine, 1974, 48, 391.

7 Troch, R, et al, Proceedings of the European Dialysis and Transplant Association, 1972, 9, 376

${ }^{8}$ Lacombe, M, Annals of Surgery, 1975, 181, 283.

$\checkmark$ Smellie, W A B, Vinik, M, and Hume, D M, Surgery, Gynecology and Obstetrics, 1969, 129, 963.

10 Malekzadeh, M H, et al, fournal of Pediatrics, 1975, 86, 370.

11 Bianchi, G, et al, Clinical Science and Molecular Medicine, 1974, 47, 435.

\title{
Pyorrhoea as cause of pyrexia
}

\author{
ELLIOT BERRY, JUSTIN SILVER
}

causes of pyrexia of undetermined origin, and a routine dental examination should be carried out in each case.

\section{Introduction}

Pyrexia of undetermined origin is always a diagnostic challenge. While most cases fall into one of three major categoriesinfection, neoplasia, or collagen disease-some $5-8 \%$ remain undiagnosed. ${ }^{1}$ We report here three cases in which prolonged fever and malaise were associated with dental sepsis.

\section{Case 1}

A 53-year-old woman was admitted because of intermittent bouts of fever of up to $39 \cdot 5^{\circ} \mathrm{C}$ for six weeks. There was no relevant history. At the start of her illness she suffered from sore throat, headache, and 